ISSN: 2521-5035 (Print)

ISSN: 2521-5043 (Online)

CODEN: ESMACU

\title{
LITHOSTRUCTURAL RELATIONSHIPS AND PETROGENETIC AFFINITIES OF THE BASEMENT COMPLEX ROCKS AROUND OKPELLA, SOUTHWESTERN NIGERIA
}

\author{
Ogunyele, A. C.* Obaje, S. O., Akingboye, A. S.
}

Department of Earth Sciences, Adekunle Ajasin University, P.M.B. 001, Akungba-Akoko, Ondo State, Nigeria *Corresponding Author's e-mail: abimbola.ogunyele@aaua.edu.ng

This is an open access article distributed under the Creative Commons Attribution License, which permits unrestricted use, distribution, and reproduction in any medium, provided the original work is properly cited

\section{ARTICLE DETAILS}

\section{Article History:}

Received 1 May 2018

Accepted 10 June 2018

Available online 7 August 2018

\begin{abstract}
Okpella area is the eastern extension of the Igarra Schist Belt, Southwestern Nigerian Basement Complex. The area comprises granite gneiss, metasedimentary rocks and Pan-African intrusives. Metasedimentary rocks occurring in the area include garnet-biotite schist, marble and calc-silicate gneiss, quartzite and Banded Iron Formation (BIF). The Pan-African intrusives include granite, charnockite, hybrid rocks, pegmatite, aplite and basic dykes. Structural data of rocks in the area suggest the presence of two contrasting structural trends. The older one which appears restricted to the granite gneiss, calc-silicate gneiss and garnetbiotite schist trends ENE-WSW to EW with moderate dips to the south. The latter NW-SE to NS trend is pervasive and occurs in all the metasediments and granite gneiss. These two trends are related to two deformational episodes and probably two orogenic periods. All the metasediments show affinity for sedimentary parentage, the granite gneiss is probably of igneous origin while the intrusives are magmatic. The charnockite-granite hybrid rock probably represents a zone of magma mixing between two contrasting magmas that were emplaced contemporaneously. The occurrence of metacarbonates in association with deformed metapelites as well as the complete absence of metavolcanics in the area suggests deposition of their protoliths in a continental environment along which crustal distention occurred. A sequence of nine geological events is suggested for the evolution of the area as deduced from field observation.
\end{abstract}

\section{KEYWORDS}

Geological evolution, Igarra Schist Belt, metasedimentary rocks, Okpella, petrogenetic affinities

\section{INTRODUCTION}

Okpella area is located in the eastern part of the Upper Proterozoic Igarra Schist Belt in the Southwestern Nigerian Basement Complex (Figure 1). The Igarra SchistBelt is made up of three majorrock groups which are [1]:

i. Migmatites, biotite and biotite-hornblende gneisses;

ii. Low grade metasediments (schists, calc-silicate gneisses, marbles, polymict metaconglomerates and quartzites); and iii. Syn- to late-tectonic porphyritic, biotite- and biotite-hornblende granites, granodiorites and adamellites, charnockites and gabbros; unmetamorphosed dolerite, pegmatite, aplite and syenite dykes.

These three major rock groups also occur around Okpella in Edo State, Nigeria. Owing to dearth of geological information on Okpella area, this paper discusses the petrology, structures and relationships, petrogenetic affinities and evolution of the Precambrian Basement Complex rocks in the area.

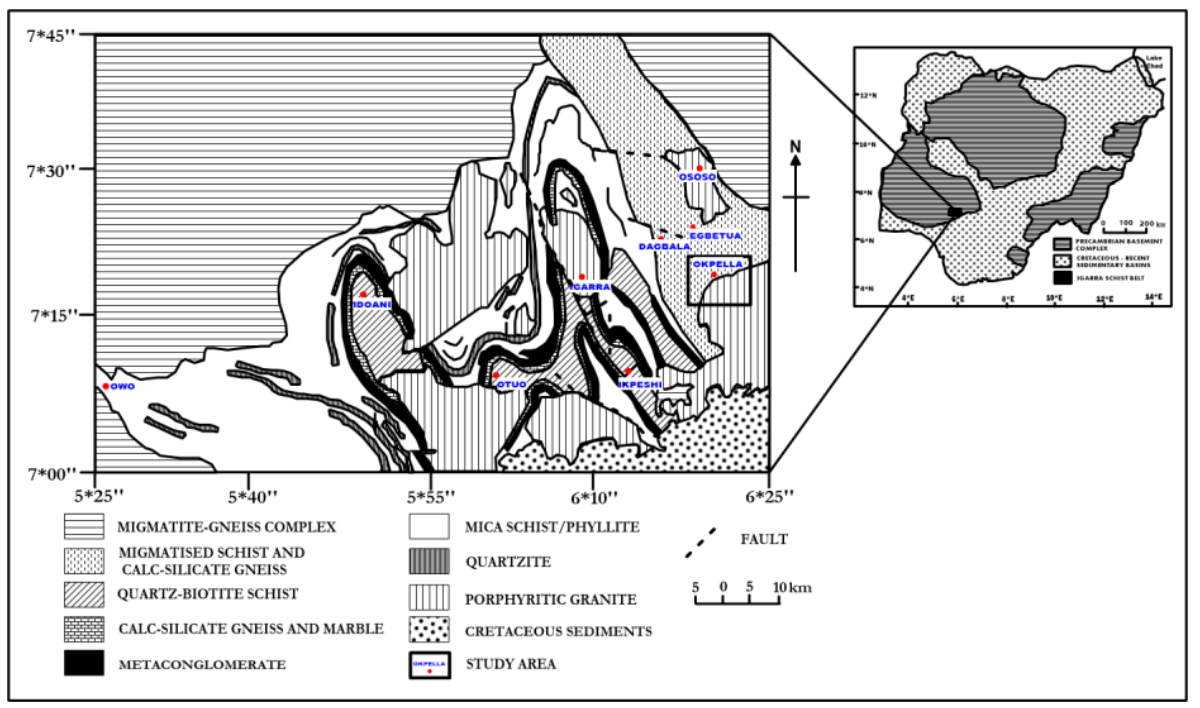

Figure 1: Geological map of Igarra Schist Belt showing Okpella area (inset: Geological map of Nigeria showing Igarra Schist Belt) [1] 


\section{METHODOLOGY}

Detailed geological and structural mapping of Okpella area on Auchi Sheet 266 NE, Nigeria was carried out. The petrology, field mineralogy, structures, relationships and locations of the rocks were determined and recorded both on the field map and in the notebook. Structural measurements such as strike and dip of planar structures, plunge and azimuth of linear structures, areal extents of rocks and other measurements were taken. The data collected from the field was used to produce the geological map of the area and also structurally analyzed using rosette diagram and stereoplots so as to determine the orientations, relationships, and types of major structures present in the area. Interpretations on petrogenesis, metamorphism and evolution of the area were carried out based on field observation, mineralogy, texture and structural relationships.

\section{RESULTS AND DISCUSSION}

\subsection{Rock types and their relationships}

The main petrologic units of Okpella area comprise granite gneiss, garnetbiotite schist, calc-silicate gneiss and marble, quartzite, Banded Iron Formation (BIF), granite, charnockite and hybrid rocks. Other minor felsic and basic rocks occurring in the area include pegmatites, vein quartz, aplite and dolerite dykes (Figure 2).

\subsubsection{Granite Gneiss}

Granite gneiss forms the basement (sensu stricto) in Okpella area. The metasedimentary rocks were deposited, metamorphosed and infolded on the granite gneiss. The granitoids (granitic and charnockitic rocks) and other minor rocks (pegmatite, aplite, vein quartz and dolerite dykes) which are the youngest lithologies are intrusive into both the granite gneiss and metasediments in the area.
The granite gneisses outcrop in the eastern part of the area. They are light grey in colour, medium to coarse grained and consist of moderately thick $(0.5 \mathrm{~cm}-2 \mathrm{~cm})$ mineralogical bands of alternating felsic (quartzofeldspathic) and mafic (biotite and hornblende) compositions (Figure 3). The contact between the granite gneiss and calc-silicate gneiss, as observed around Freedom Group Company along the Benin-Okene expressway, is characterised by the occurrence of pink feldspar-rich pegmatite which is about $30 \mathrm{~m}$ wide and $1.5 \mathrm{~km}$ long (Figure 4). At the contact, abundant pegmatite dykes, sills and lenses that have been faulted, jointed and folded occur within the granite gneiss.

\subsubsection{Garnet-Biotite Schist}

Garnet-biotite schist outcrop extensively as low-lying rocks in the central and northwestern part s of Okpella. The rock is schistose, dark grey to black in colour and fine to medium grained. It contains abundant quartz, biotite, plagioclase feldspar, K-feldspar and porphyroblasts of red garnets. The garnet porphyroblasts sometimes exceed $3 \mathrm{~cm}$ in size and are often aligned along the rock's strike.

The schist probably covers more area in the past than it presently outcrops. This is evident by the abundance of the rock as both small and giant xenoliths within charnockites and granites which occur to its south. Around the charnockite-granite boundary in the central part of the area, a fairly extensive outcrop of the garnet-biotite schist, about $700 \mathrm{~m}$ long and $300 \mathrm{~m}$ wide, was mapped.

The schist have been intruded by pegmatites, vein quartz and granite, sometimes forming a sequence of intricately folded and fractured schistgranite-pegmatite bodywith each rock type less than $50 \mathrm{~m}$ wide (Figure 4).

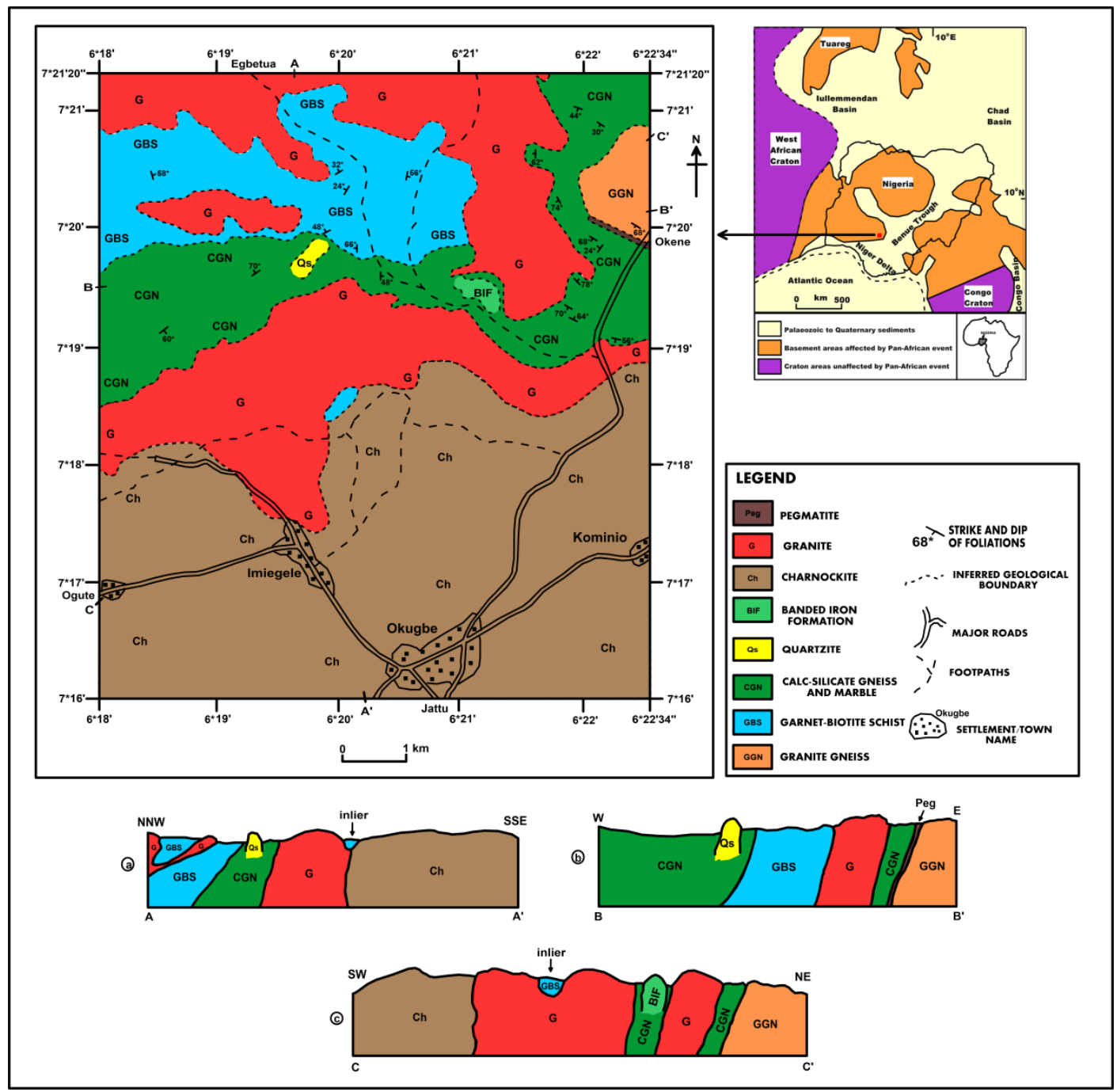

Figure 2: Geological map and cross sections of Okpella area, Auchi Sheet 266 NE Nigeria [inset: Regional geological setting of Nigeria (modified after 2)] 


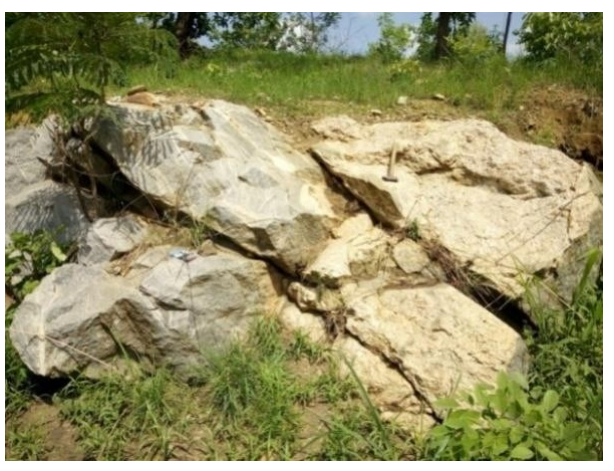

Figure 3: Feldspar-rich pegmatite at the contact between granite gneiss and calc-silicate gneiss at Okpella

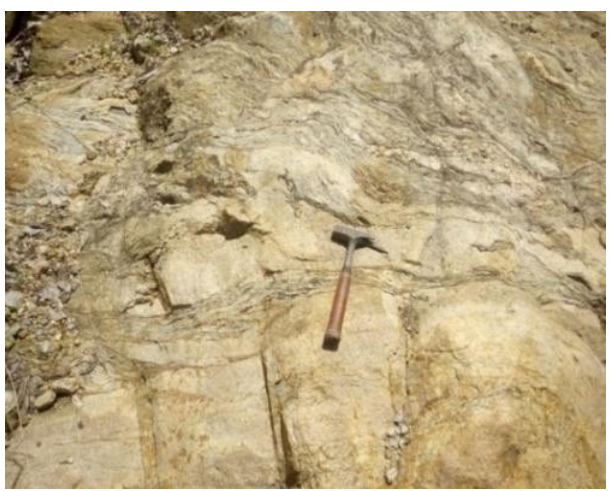

Figure 4: Garnet-biotite schist intruded by granite and pegmatite

\subsubsection{Calc-silicate Gneiss and Marble}

Calc-silicate gneiss and marble occur in the central part of Okpella area. The calc-silicate gneiss is more abundant than marble and is foliated, folded, dark green to dark grey, fine-medium grained and often associated with marble and granitic bands, pegmatitesand quartzveins. It consists of alternating bands of light (quartz- and calcite-rich), dark grey (biotiterich), and dark green (calcite, actinolite and tremolite) colours.

Weakly foliated and massive marble varieties occur in association with calc-silicate gneisses in the area. The foliated marbles are found at the contact of marble with granite around BUACementCompany Quarry. The foliated marbles contain white (calcite), pink (calcite) and dark green (dolomitic) bands.

Away from the contact, massive (non-foliated) marble outcrops. The massive marbles are coarse grained,equigranular, and composed mainly of euhedral calcite crystals with subordinate amounts of graphite (black specks), chlorite and epidote (green). Most of the massive marbles are white to creamy in colour (Figure 5). A pink massive variety of marble also occur in the area. In some places, marble veins and lenses cuts through calc-silicate gneisses suggesting that the latter is older.

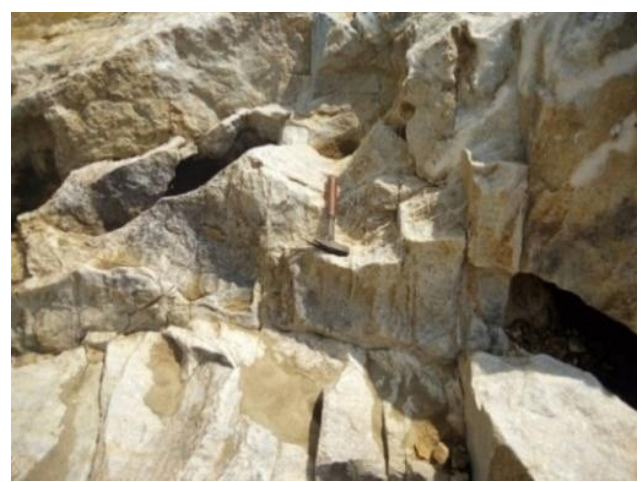

Figure 5: Okpella massive marble

\subsubsection{Quartzite and Banded Iron Formation (BIF)}

Foliated quartzite and Banded Iron Formation occur as ridges within calc-silicate gneiss andmarble in the area. The NE trending quartziteridge is partly ferruginized, highly weathered and covered by thick vegetation and weathered quartzite rubble.

Fresh samples of the quartzite show that the rock is composed mainly of quartz with minor amounts of muscovite, iron minerals and green actinolite-tremolite. Veinlets of quartz probably formed by partial melting, often cross-cut the rock fabric.

The BIF is reddish brown to black in colour, banded, highly indurated and folded (Figure 7). It is composed mainly of iron minerals and quartz. Concretions of iron are also conspicuous in the iron ore. The texture ranges from fine to coarse grained with some quartz pebbles and cobbles. The BIF ridge is thickly vegetated and covered by large boulders and lateritic soils. Occurrence of BIF in this part of Igarra Schist Belt may indicate a link between the area and the nearby Okene migmatitic complex where the Itakpe BIF and other iron formations occur $[3,4]$.

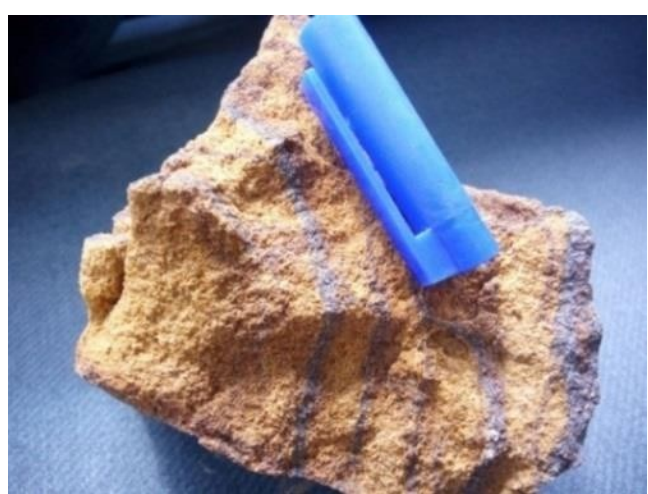

Figure 6: Typical sample of Okpella Banded Iron Formation (BIF)

\subsubsection{Granitoids}

Granitoids occurring around Okpella include charnockite, granite, hybrid rocks and minor rocks. Okpella charnockites are of two textural varieties: coarse and fine-medium charnockites. The coarse charnockites (Figure 7a) are the most abundant variety, dark green to dark grey in colour and are very coarse grained with most crystals often exceeding $2 \mathrm{~cm}$, and sometimes exhibiting porphyritic texture. This variety comprises of welldeveloped (euhedral to subhedral) crystals of quartz, feldspars, hypersthene, biotite, hornblende and iron minerals. The coarse charnockites intrude the garnet-biotite schist, marble and calc-silicate gneiss. Xenoliths of garnet-biotite schist, sometimes as extensive as $20 \mathrm{~m} \mathrm{x}$ $10 \mathrm{~m}$, occur within the coarse charnockite. Also within the coarse charnockites, fine-medium charnockite occur as large xenoliths (Figure 7b). This fine-medium variety probably represents the early charnockitic rocks to crystallise. They are fine-medium grained, dark green, and contain hypersthene, quartz, Kfeldspar, plagioclase feldspar, garnet, biotite, hornblende and iron minerals. In some locations, coarse charnockites have intensely mixed and reacted with garnet-biotite schist to form a hybrid. Both the hybrid rock and fine-medium charnockite are garnetbearing.

Granitic rocks rich in quartz, Kfeldspar, plagioclase feldspar, biotite and hornblende form batholiths in the area. The granites often contain xenoliths of the calc-silicate gneiss and schist (Figure 7c). Coarseporphyritic and medium-coarse granite varieties occur in the area. The granite and charnockite are closely associated and the formation of a hybrid of both rock types reveals that the magmas that produced the two rock types were probably emplaced contemporaneously. Other rocks that occur in the area include pegmatites, aplites, quartz veins and lenses and basic dykes which intrude all the other rock types. 


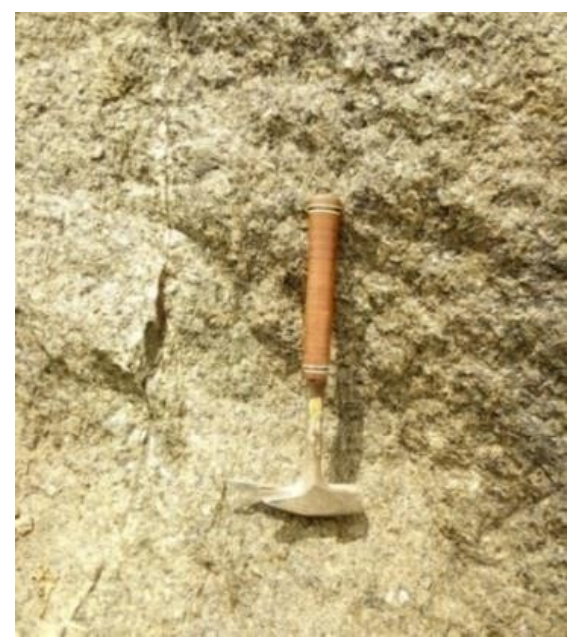

Figure 7a: Okpella coarse charnockite

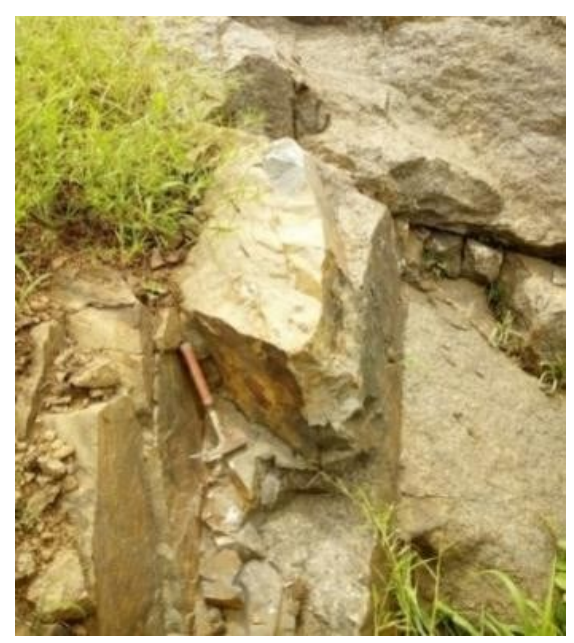

Figure 7b: Xenolith of fine-medium charnockite within coarse charnockite

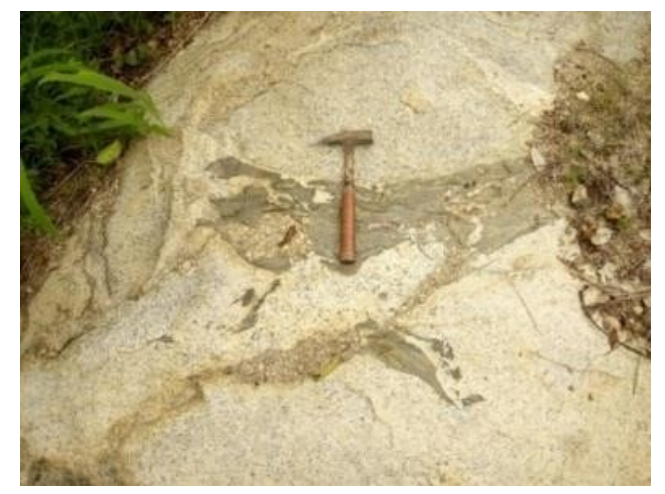

Figure 7c: Xenoliths of calc-silicate gneiss in medium-coarse granite around Edo Cement Company, Okpella

\subsection{Structural Features and Analysis}

Structural features identified in the Precambrian Basement Complex rocks of Okpella area include: foliation, folds, faults, fault zone, joints, boudinage, lineations and microstructures.

\subsubsection{Foliation}

Field observation, structural data and analysis revealed that there are two foliation trends in the Precambrian Basement Complex rocks of Okpella area (Figure 8a). These two trends are probably related to two deformational phases $\left(D_{1}\right.$ and $\left.D_{2}\right)$ [1]. The first trend, which is a minor trend, is an ENE-WSW to EW trend $\left(\mathrm{S}_{1}\right)$, produced by the first deformation $\left(D_{1}\right)$, and is observed mainly on the calc-silicate gneiss and to some extent on the garnet-biotite schist and granite gneiss. The garnet-biotite schist is more migmatised than the calc-silicate gneiss and as a result the foliation trend is not easy to identify probably due to obliteration by the second deformation $\left(D_{2}\right)$. This foliation trend has a moderate dip (averagely $56^{\circ}$ ) to the south.

The second and major foliation trend $\left(\mathrm{S}_{2}\right)$ which is pervasive and occurs in all the metasediments and granite gneiss is variable but is generally NW-SE to NS. The dips are also variable from east to west, but the western dip is more abundant. These alternating dip directions observed particularly on the calc-silicate gneiss and garnet-biotite schist in the central and northeastern parts of Okpella possibly suggest the presence of major folds in the area.

Three generations of pegmatites, quartz veins and aplites were observed in the area and on the rosette diagram (Figure 8b). They trend approximately NNW-SSE to NS, NE-SW and EW. Field relationships revealed that the NNW-SSE to NS trending pegmatites and veins are older than the NE-SW trending pegmatites and veins.

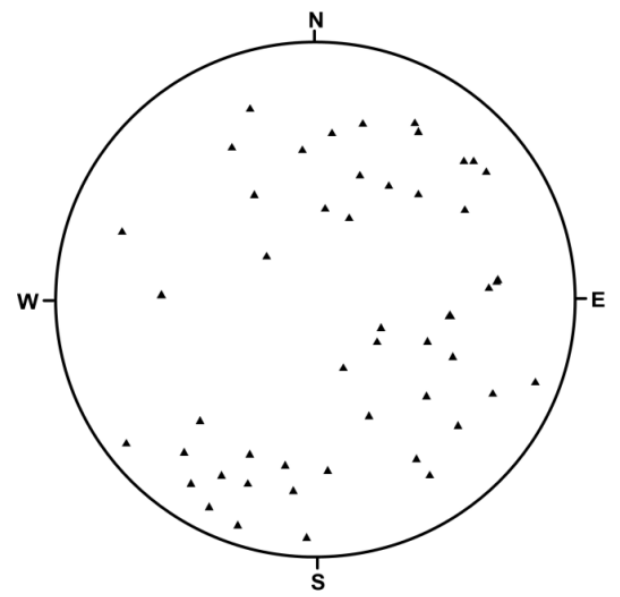

Figure 8a: Stereoplot of the foliation trends of Okpella metasediments and granite gneiss

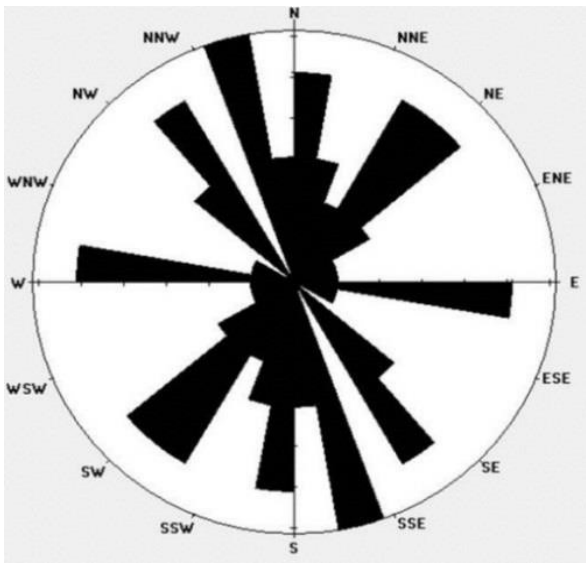

Figure 8b: Rose diagram of the trends of minor rocks around Okpella 


\subsubsection{Folds}

Minor folds observed on rock outcrops around Okpella are classified into two groups, $F_{1}$ and $F_{2}$, and are related to the two deformation phases that occurred in the area. The $\mathrm{F}_{1}$ folds have an ENE-WSW to EW axial plane and are colinear with $S_{1}$. They are mainly ptygmatic, tight to isoclinal (Figure 9a). The $F_{2}$ folds have an approximately NS axial plane and are colinear with $S_{2}$. The $F_{2}$ folds are open (symmetrical) to asymmetrical to isoclinal (Figures 9b-d).

From field study, structural data and analysis, it is clearly observed that at least two major folds occur in the northern part of Okpella area. To determine the type of fold, the area was divided into three quadrants (A, B and C) and field data collected from these quadrants were structurally analysed using a Lambert Equal area net (Figure 10).

The S-pole diagram of quadrants A and B shows a spread around a great circle with two maxima indicating the structure as a slightly inclined, plunging, asymmetrical fold with a fold axis of $32^{\circ} / 248^{\circ}$ and fold axial plane of $68^{\circ} / 88^{\circ}$. The fold in this areais probably a synform. The fold type in quadrants $\mathrm{B}$ and $\mathrm{C}$ is an upright, plunging, angular (chevron) fold having a fold axis of $08^{\circ} / 294^{\circ}$ and fold axial plane of $144^{\circ} / 90^{\circ}$.

\subsubsection{Fault and Joint}

Minor normal faults and strike-slip faults occur in granites and pegmatites within calc-silicate gneiss, schist and granite gneiss in Okpella area. The central and northern parts of Okpella area where the calc-silicate gneiss and garnet-biotite schist have been largely intruded by granites and pegmatites and forms a sequence (Figure 4) appear to be a major fault zone in the area. This zone may be connected to that of Ekpedo-Dagbala-Atte areas to the northwest of Okpella area (Figure 1).

Joints are abundant in Okpella area particularly on the calc-silicate gneiss, charnockites and granites. The rosette diagram of joints in the area (Figure 11) shows that most joints trend NS with minor trends in the ENE-WSW toE-W directions.

\subsubsection{Boudinage}

Boudinage structures mostly trending approximately NS occur within calc-silicate gneisses in Okpella area. The boundins are made up of either quartz or pegmatites. The presence of boudinage structure in the calcsilicate gneisses indicates the occurrence of extensional stress on the quartz veins and pegmatites (competent rock) within the calc-silicate gneiss (incompetent rock), probably during the later stage deformation $\left(D_{2}\right)$.

\subsubsection{Lineation}

Mineral lineations, although less well preserved, occurs in some calcsilicate gneisses and marble in Okpella area. This lineation is defined by alignment of mica and iron minerals with plunges of $40^{\circ}-70^{\circ}$ towards $320^{\circ}$.
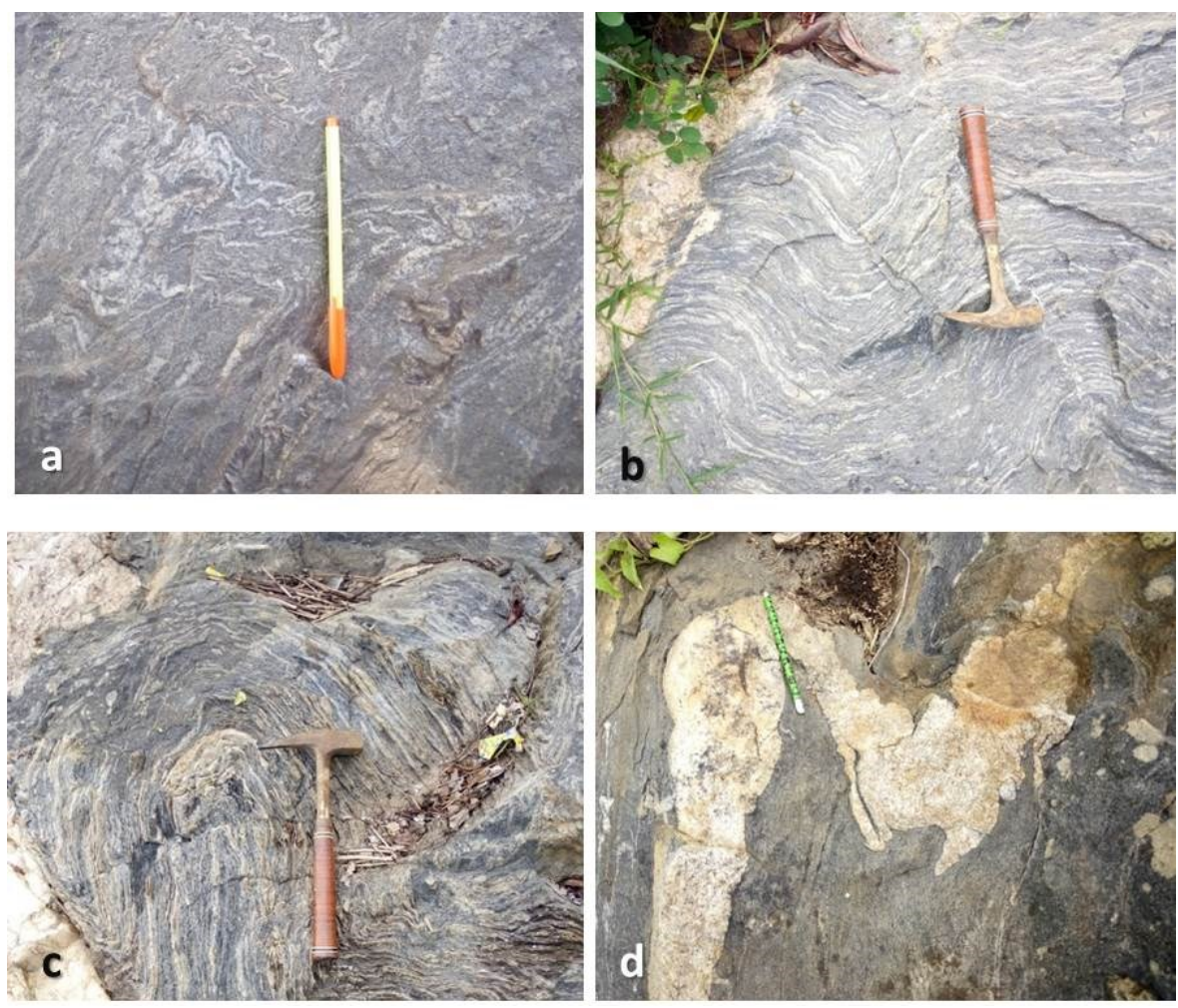

Figure 9: Field photographs showing (a) $F_{1}$ tight folds in garnet-biotite schist; (b) $F_{2}$ open folds in calc-silicate gneiss;

(c) $F_{2}$ tight folds in calc-silicate gneiss; and $F_{2}$ asymmetrical fold in pegmatite in calc-silicate gneiss. 


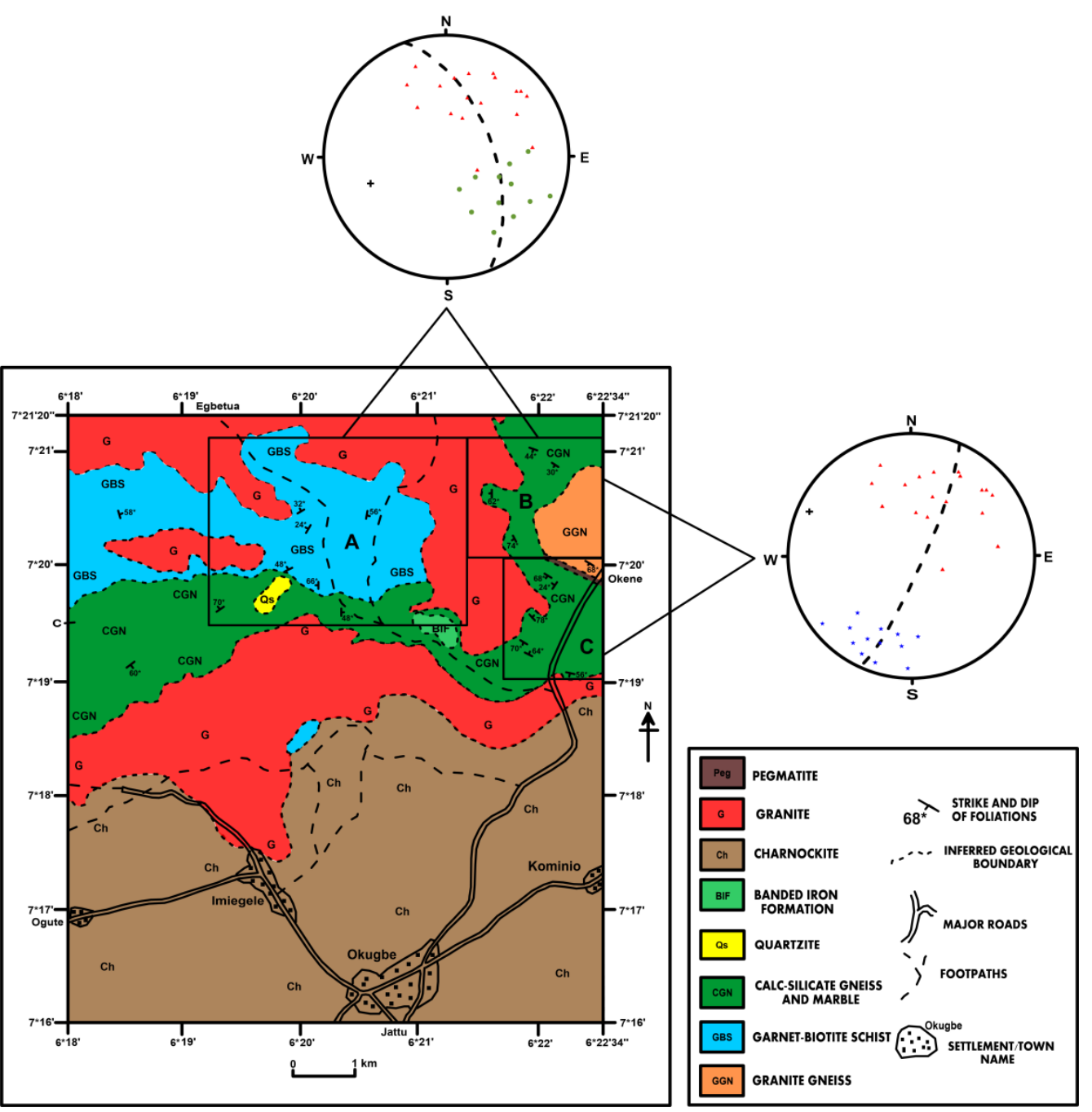

Figure 10: Pi plot of S-pole data for the rocks in the northern part of Okpella area

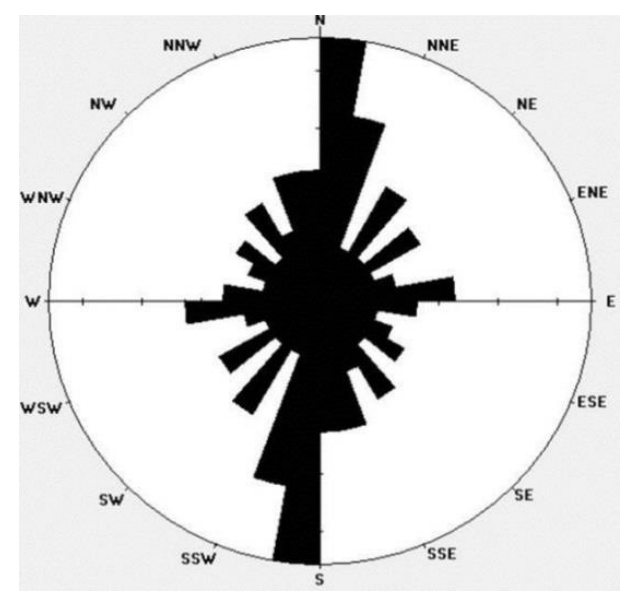

Figure 11: Rose diagram of joints in Okpella area

\subsection{Petrogenetic Affinities}

The granite gneiss is probably of igneous parentage. This is evidenced by the absence of typical aluminosilicates such as kyanite, sillimanite, andalusite and other minerals (cordierite, garnet, staurolite, etc) which normally indicates sedimentary parentage in the gneiss. Field data strongly suggest sedimentary origin for the garnet-biotite schist, calcsilicate gneiss, marble, quartzite and Banded Iron Formation. The garnetbiotite schist represents metamorphosed pelitic or argillaceous rocks (shale or siltstone) [5]. The occurrence of garnet, biotite, and quartz in the rock confirms this suggestion [6,7].
The calc-silicate gneiss has silty-sandy limestone, dolostone or marly source rock origin. The association of quartzite with calc-silicate gneiss confirms the sedimentary parentage of both rocks. Magmatic fluids from intruding magma may have affected the composition of the calc- silicate gneisses. The marble, particularly the massive variety probably represents pure limestones. The occurrence of marble veins and lenses in the calc-silicate gneisses suggest that the marble was probably formed from carbonate-rich hydrothermal fluids.

Another possible mode of origin of the marble veins is the dewatering of the carbonate sedimentary protolith(s) of themarble duringmetamorphism resulting in the formation of carbonate-rich fluid(s) which was subsequently mobilized, deposited and crystallised as veins in fractures, foliation planes and other planes of weaknesses within the associated calc-silicate gneisses. The quartzite was formed as a result of metamorphism of sandstone, probably graywacke. The Banded Iron Formation (BIF) was probably formed from ferruginous sandstone as revealed by its texture and mineralogy. Banding in the iron ore resulted from the metamorphism of the bedding of its ferruginous sedimentary (psammitic) protolith.

The granite, charnockite, hybrid rocks and other minor felsic and basic rocks are magmatic in origin. The formation of garnet in the coarse charnockite-schist hybrid rock and the medium charnockite is attributed to the garnet in the schistose host rock. The charnockitic magma during its crystallisation assimilated the schist material, thus providing suitable bulk composition for the formation of garnet in these rocks. The coarse charnockite-granite hybrid rock possibly represents a zone of magma mixing between two contrasting magmas that were emplaced contemporaneously [8]. The occurrence of metacarbonates in association with deformed metapelites as well as the complete absence of metavolcanics in the area suggests deposition of their protoliths in a continental environment along which crustal distention has occurred [912]. 


\subsection{Metamorphism}

The metasediments in Okpella area have been subjected to probably two phases of metamorphism $\left(\mathrm{M}_{1}\right.$ and $\left.\mathrm{M}_{2}\right)$ indicating the early metamorphism $\left(M_{1}\right)$ of their sedimentary protoliths and a later metamorphism $\left(M_{2}\right)$ of the metasediments during the Pan-African orogeny.

Although most parts of the Igarra Schist Belt attained a greenschist metamorphic facies grade, this study revealed that Okpella area locally attained a medium metamorphic grade, probably of lower amphibolite facies [1,13]. The strong deformation and paragenesis of the metasediments particularly the calc-silicate gneiss and garnet-biotite schist as well as the mineral assemblage of garnet, biotite, and quartz in the garnet-biotite schist attest to this suggestion $[14,15]$.

\subsection{Evolution/Geological History}

The suggested sequence of geological events in the Precambrian Basement Complex of Okpella area as deduced from detailed geological and structural mapping is shown in Table 1 and Figure 12.

Table 1: Suggested sequence of geological events in Okpella area

\begin{tabular}{|c|c|c|}
\hline $\mathbf{S} / \mathbf{N}$ & Geological Events & Age \\
\hline 9 & Final shearing, uplift and weathering & Post-Pan-African \\
\hline 8 & Emplacement of undeformed basic dykes & \multirow{2}{*}{ Late Pan-African } \\
\hline 7 & Emplacement of pegmatites and vein quartz & \\
\hline 6 & $\begin{array}{l}\text { Metamorphism }\left(\mathrm{M}_{2}\right) \text { and deformation }\left(\mathrm{D}_{2}\right) \text { of the granite gneiss and } \\
\text { metasediments }\end{array}$ & \multirow{2}{*}{$\begin{array}{l}\text { Early to main stage Pan-African } \\
(600 \pm 150 \text { m.y.) }\end{array}$} \\
\hline 5 & Emplacement of charnockites and granites & \\
\hline 4 & $\begin{array}{l}\text { Metamorphism }\left(\mathrm{M}_{1}\right) \text { and deformation }\left(\mathrm{D}_{1}\right) \text { of the granite gneiss and sediments to } \\
\text { form garnet-biotite schist, calc-silicate gneiss and marble, quartzite and ironstone }\end{array}$ & \multirow{3}{*}{$\begin{array}{l}\text { Early Pan-African?? } \\
(600 \pm 150 \text { m.y. })\end{array}$} \\
\hline 3 & Deposition of shale, siltstone, sandstone, limestone and marls & \\
\hline 2 & Formation of a shallow basin & \\
\hline 1 & Emplacement of granitic rocks which was metamorphosed to form granite gneiss & $\begin{array}{l}\text { Eburnean??? } \\
(2000 \pm 150 \text { m.y. })\end{array}$ \\
\hline
\end{tabular}

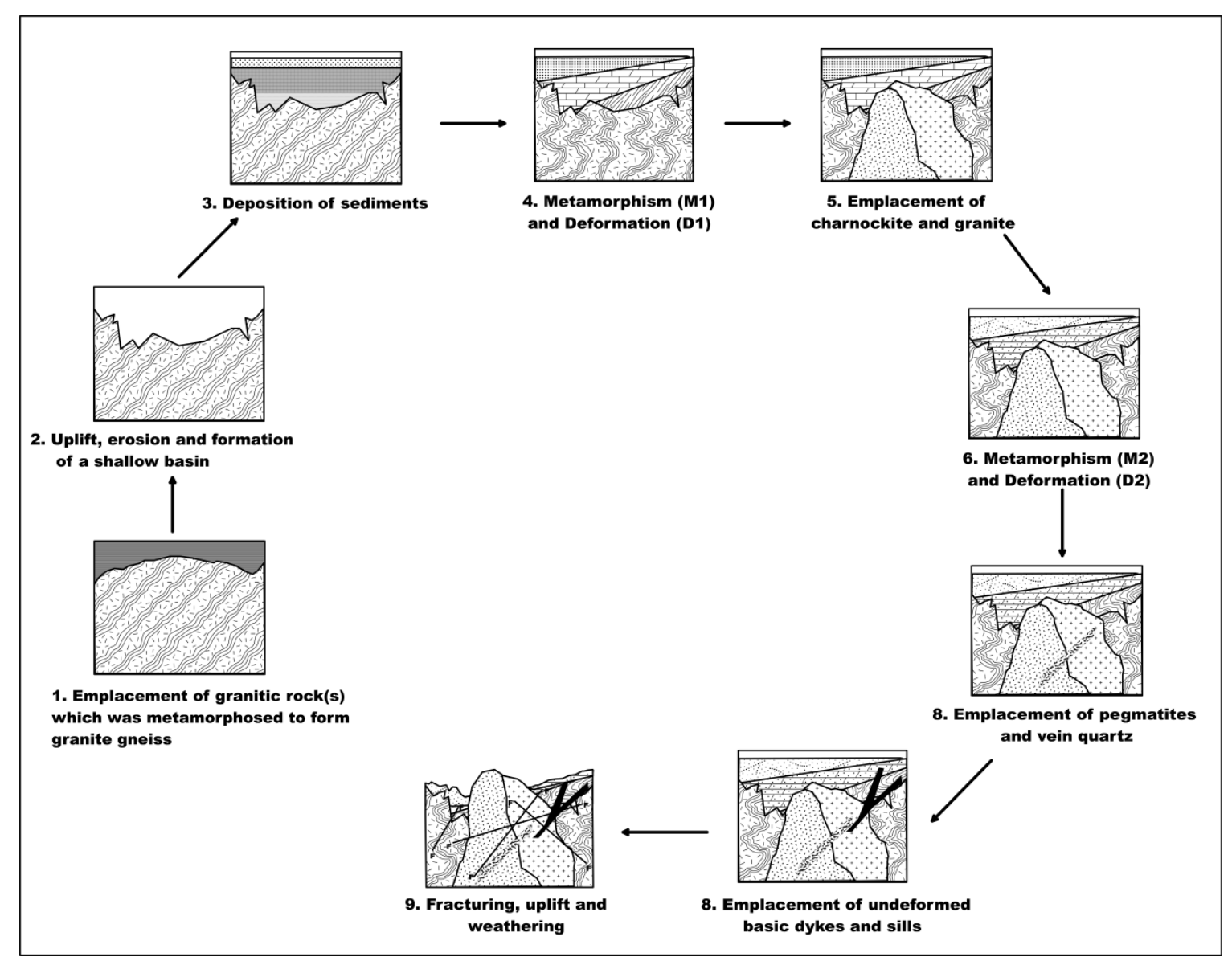

Figure 12: Geological model showing the suggested evolution of Okpella area 


\section{CONCLUSION}

The petrology of Okpella area revealed that the area comprises granite gneiss, metasedimentary rocks and Pan-African intrusives. Structural data and analysis revealed two foliation and fold trends which are probably related to two deformation periods and orogenic episodes. At least two major folds also occur in the area.

The granite gneiss is probably of igneous parentage. Petrological data, however strongly suggest sedimentary origin for the garnet-biotite schist, calc-silicate gneiss, marble, quartzite and Banded Iron Formation. The Pan-African intrusives are magmatic.

Okpella area locally attained a medium metamorphic grade, probably of lower amphibolite facies. A sequence of nine geological events ranging from emplacement of granitic protolith(s) of the granite gneiss to final shearing, uplift and weathering was suggested for the area.

\section{REFERENCES}

[1] Odeyemi, I.B. 1988. Lithostratigraphy and Structural Relationships of the Upper Precambrian Metasediments in Igarra area, Southwestern Nigeria. In: Oluyide, P.O., Mbonu, W.C., Ogezi, A.E.O., Egbuniwe, I.G., Ajibade, A.C. and Umeji, A.C. (eds.) Precambrian Geology of Nigeria. Geological Survey of Nigeria, Kaduna,111-125.

[2] Woakes, M., Rahaman, M.A., Ajibade, A.C. 1987. Some Metallogenetic Features of the Nigerian Basement. Journal of African Earth Sciences, 6 (5), 655-664

[3] Adegbuyi, O., Olade, M.A. 1990. The Precambrian Itakpe Iron Deposit in Central Nigeria. In: Ancient Banded Iron Formations. Theophrastus Publication, S. A. Athens, Greece,105-118.

[4] Annor, A.E. 1998. Structural and Chronological Relationship between the low grade Igarra Schist and its adjoining Okene Migmatite-Gneiss Terrain in the Precambrian exposure of Southwestern Nigeria. Journal of Mining and Geology,34,187-196.
[5] Adegbuyi, 0., Ogunyele, A.C., Odindu, M., Erinfolami, T.G. 2017. Geochemical Characteristics and Petrogenesis of Basement Rocks in Idoani Area, Ondo State, Southwestern Nigeria. International Journal of Advanced Geosciences, 5 (2), 102- 108.

[6] Best, M.G. 2002. Igneous and Metamorphic Petrology. $2^{\text {nd }}$ ed. WileyBlackwell.

[7] Bucher, K., Grapes, R. 2011. Petrogenesis of Metamorphic Rocks. $8^{\text {th }}$ ed. Springer-Verlag, Berlin Heidelberg.

[8] Olarewaju, V.0. 1999. Fluid Inclusion Studies of coarse-grained Charnockitic and the Hybrid Rocks in Ukpilla area, Southwestern Nigeria. Journal of Mining and Geology, 35(1), 1-7.

[9] Elueze, A.A. 1991. Rift system for Proterozoic Schist Belts in Nigeria. Tectonophysics, 209, 167-168.

[10] Hoeffs, J. 1997. Stable isotope geochemistry. Springer BerlinHedelberg, New York, 195.

[11] Elueze, A.A., Okunlola, O.A. 2003. Petrochemical and Petrogenetic Characteristics of Metasedimentary Rocks of Lokoja-Jakura Schist Belt, Central Nigeria. Journal of Mining and Geology, 39(1), 21-23.

[12] Okunlola, O.A. 2017. Riches beneath our Feet: Mineral Endowment and Sustainable Development of Nigeria. Inaugural Lecture delivered at University of Ibadan.

[13] Ocan, O., Coker, S.J., Egbuniwe, I.G. 2003. The Geology of Igarra-Auchi Area. Excursion Guide at the Annual Conference of the Nigerian Mining and Geosciences Society (NMGS),Itakpe.

[14] Ekwueme, B.N. 2003. The Precambrian Geology and Evolution of the Southeastern Nigerian Basement Complex. University of Calabar Press.

[15] Rahaman, M.A. 1988. Recent Advances in the Study of the Basement Complex of Nigeria. In: Oluyide, P.0., Mbonu, W.C., Ogezi, A.E.O., Egbuniwe, I.G., Ajibade, A.C. and Umeji, A.C. (eds.) Precambrian Geology of Nigeria. Geological Survey of Nigeria, Kaduna, 11-43. 